NBER WORKING PAPER SERIES

\title{
CHOOSING BETWEEN PEACE AND WAR
}

\author{
Herschel I. Grossman \\ Working Paper 10180 \\ http://www.nber.org/papers/w10180 \\ NATIONAL BUREAU OF ECONOMIC RESEARCH \\ 1050 Massachusetts Avenue \\ Cambridge, MA 02138 \\ December 2003
}

Revised version of the Timlin Lecture, delivered at the University of Saskatchewan on October 27, 2003. Luciana Fiorini gave me valuable assistance in preparing this lecture. The views expressed herein are those of the authors and not necessarily those of the National Bureau of Economic Research.

(C2003 by Herschel I. Grossman. All rights reserved. Short sections of text, not to exceed two paragraphs, may be quoted without explicit permission provided that full credit, including $\mathbb{C}$ notice, is given to the source. 
Choosing Between Peace and War

Herschel I. Grossman

NBER Working Paper No. 10180

December 2003

JEL No. D74, H56

\section{ABSTRACT}

Although most disputes between groups of people are settled peacefully, sometimes disputes result in war. This lecture uses historical examples to illustrate how the ability to negotiate a credible peaceful settlement of a dispute between sovereign states, typically a dispute over the control of territory or natural resources, depends on the divisibility of the outcome of the dispute, on the effectiveness of the fortifications and counterattacks with which an attacker would expect to have to contend, and on the permanence of the outcome of a potential war. The lecture also contrasts the possibilities for avoiding wars between sovereign states with the possibilities for avoiding civil wars.

Herschel I. Grossman

Department of Economics

Box B

Brown University

Providence, RI 02912

and NBER

herschel_grossman@brown.edu 
Since Adam and Eve were expelled from the Garden of Eden, the Four Horsemen of the Apocalypse have wrecked their havoc on mankind. Although the meaning of the metaphor of the Four Horsemen remains subject to ongoing scholarly controversies, we can take the Four Horsemen to represent famine, disease, natural disasters, and the subject of this lecture, war. $^{1}$

In modern times science and technology have mitigated the ravages of three of the Four Horsemen. Improvements in agriculture and in transportation have helped to alleviate famine and to feed growing populations, medical science and public health have made steady progress in finding and effecting preventions and cures for diseases, and advances in structural and civil engineering have resulted in better protection from natural disasters.

War, however, continues to be both an acute problem and a puzzle. I call war a puzzle because, this horseman being wholly man made, we might think that it would be easy to relieve ourselves of his torments. But, despite our achievements in science and technology, and in profound humanistic thinking, we have not made noticeable progress in solving the problem of war. A comparison of modern times with what we know about human history suggests that wars, both wars between sovereign states and civil wars, are as common now as they ever have been.

People sometimes attempt to explain the persistence of war by claiming that wars are an inevitable consequence of "human nature". There are both scientific and religious versions

\footnotetext{
${ }^{1}$ These controversies involve biblical exegesis and the interpretation of medieval iconography, The proximate source of the metaphor of the Four Horsemen is the New Testament Book of Revelation. Earlier sources include the Old Testament Books of Ezekiel and Zechariah. The Four Horsemen have often been popularized, perhaps most famously by the artist Albrecht Dürer in his brilliant woodcut of 1498 and by the sports writer Grantland Rice, who used the metaphor, with slightly different names for the Horsemen, to romanticize the 1924 University of Notre Dame football team.

Outlined against a blue-gray October sky, the Four Horsemen rode again. In dramatic lore, they are known as famine, pestilence, destruction and death. These are only aliases. Their real names are Stuhldreher, Miller, Crowley and Layden.
} 
of this claim. A scientific version is that evolution has hardwired into us a proclivity for groups of people to fight with other groups of people. According to this theory we will see an end to war only if future evolutionary developments bring about a salutary change in human nature.

A religious version of the claim that war results inevitably from human nature is that people, or at least some people, are innately sinful and unable to eschew violence. According to this theory an end to war must await the coming of a messianic age in which divine intervention will change human nature.

\section{Disputes, Peaceful Settlements, and Wars}

Whether based on science or religion the claim that human nature makes war inevitable overlooks a critical observation:

Disputes between groups of people, and an accompanying potential for war, are ubiquitous, but the use of war to settle disputes, although it happens painfully often, is not ubiquitous.

Because people are materialistic and acquisitive, and also can have strong views about ideological issues, groups of people have disputes about all manner of things. Disputes between sovereign states, as well as disputes about secession, in which a group wants to break away and to create a new sovereign state, typically involve the control of territory and natural resources. In contrast, disputes between factions within a sovereign state - that is, between groups that are part of the same polity — typically involve either the distribution of political power and income or religion and other ideological issues.

The important fact, however, is that, regardless of their nature, most disputes between groups of people are settled peacefully. Only a small fraction of disputes between sovereign states result in inter-state war, and only a small fraction of disputes between constituent groups of a polity result in civil war. Even disputes about secession are often settled peacefully and only sometimes result in wars of independence. 
The fact that most disputes are settled peacefully belies the claim that war is an inevitable consequence of human nature. This fact also directs us to the central question:

Although human nature apparently does not preclude the peaceful settlement of disputes, why do some disputes result in war?

As a social scientist I presume that this question affords a general set of answers. That is to say, I presume that wars are not wholly idiosyncratic. In addition, to address this question I presume that war is instrumental, by which I mean that war is a means that groups sometimes choose to employ in attempting to settle a dispute favorably.

War, however, is a problematical instrument for settling a dispute, because war is costly and risky. When groups arm, they incur the cost of mobilizing resources that have alternative productive uses. In addition, war causes havoc in the form of destruction, suffering, and death. War also involves risks, which include the possibility that either the cost of mobilizing resources or the resulting havoc will turn out to be larger than expected, the fear of each member of a group that he (or she) will incur a disproportionately large share of the cost or the havoc, and the fear of each group that it might lose the war.

Although war is costly and risky, taking the groups involved in a dispute together, war cannot provide any compensating gain, because the outcome of a dispute can be more favorable to one group only if it is less favorable to the other group. Accordingly, it is natural to conjecture that every dispute affords a peaceful settlement that avoids war. Moreover, we should not be surprised that groups usually settle their disputes peacefully, sometimes by one group conceding to the demands of the other, but more often by reaching a compromise in which both groups gain something without incurring the costs of mobilizing resources, without suffering the havoc of war, and without bearing the risks of war. But, then we come back to the earlier question: Why aren't all disputes settled peacefully? Given the presumption that war is instrumental, an answer to this question requires an understanding of how groups choose between peace and war in settling disputes. 


\section{The Oregon Treaty and the Mexican-American War}

To begin let us focus on territorial disputes between sovereign states, starting with an example that is close to home. ${ }^{2}$ In the 1840s two territorial disputes, one between the United States and Great Britain and the other between the United States and Mexico, permanently shaped the political map of North America. ${ }^{3}$ The Democratic candidate, James Polk, won the American presidential election of 1844 on a platform that asserted the American claim to the entire Oregon territory, including the part that later became British Columbia. The political slogan "Fifty-four Forty or Fight!", a reference to 54 degrees 40 minutes north latitude, dramatized this claim. ${ }^{4}$

But, the outcome of this territorial dispute was neither fifty-four forty nor fight. In the Oregon Treaty of 1846 the United States and Great Britain peacefully settled the dispute by

\footnotetext{
${ }^{2}$ See Herschel Grossman (2003c) for a formalization of the analysis of territoral disputes that follows.
} This analysis assumes that, as in the dispute between the United States and Great Britain over the Oregon territory, the preferences of the inhabitants of the contested territory play no role. In a complementary analysis Alberto Alesina and Enrico Spolaore (1997, 2003, 2004) assume that preferences for public goods, including collective security, determine the incorporation of regions into sovereign states. The analysis that follows also assumes that states act in the territorial disputes as if they are unitary agents and, hence, that their internal politics do not bear on these disputes. Examples of recent literature on the relation between politics and war include Michelle Garfinkel (1994) and Gregory Hess and Athanasios Orphanides $(1995,2001)$. Finally, the analysis that follows assumes that neither state is a Stackelberg leader, who could make an irreversible choice to arm before the other state arms. The analyses in Grossman and Minseong Kim (1995), Dmitriy Gershenson and Grossman (2000), and Grossman and Juan Mendoza (2002), suggest conditions under which a Stackelberg leader would choose to spend enough on arms to cause the other state to give up its claim to the contested territory.

${ }^{3}$ David Pletcher (1973) provides an extensive account of political, diplomatic, and military developments in these simultaneous territorial disputes.

${ }^{4}$ The origin of the slogan is obscure. Both Edwin Miles (1957) and Hans Sperber (1957) conclude that, contrary to some accounts, it was not used during the election campaign of 1844 , but originated during the congressional debates that followed the election. 
dividing the Oregon territory between the United States and Canada. The Oregon Treaty also conceded a British demand for rights of navigation on the Columbia River, although the Columbia River turned out not to be usefully navigable anyhow.

In the decades following the Oregon Treaty the United States and Great Britain peacefully settled additional territorial disputes that arose over the San Juan Islands, rights to hunt fur seals, and the boundary of Alaska. These settlements completed the demarcation of the current border between the United States and Canada.

In sharp contrast to the peaceful settlement of the dispute over the Oregon territory, in the same year, 1846, territorial disputes between the United States and Mexico led to war, with disastrous consequences for Mexico. As the result of the Mexican-American War the United States annexed previously Mexican territories that now comprise Arizona, California, Nevada, New Mexico, Utah, and parts of Colorado and Texas.

These historical accounts leave us with the following question: What was importantly different about the territorial disputes between the United States and Great Britain and between the United States and Mexico that allowed the United States and Great Britain, like most sovereign states that have territorial disputes, to reach a peaceful settlement, whereas the United States and Mexico went to war?

As a schoolboy I learned with pride that the United States and Canada enjoyed the world's longest unfortified border between sovereign states. In addition, my elders led me to believe that this happy state of affairs resulted from the moral superiority of Americans and Canadians, especially in contrast to Mexicans and also to Europeans, who, being greedy and quarrelsome, regularly fought wasteful and destructive wars, the Second World War that had just ended being the latest example.

If we wish to, we can believe that we are morally superior. But, a theory of the choice between peace and war offers less invidious explanations for differences in the ways in which disputes between sovereign states have been resolved. What are these explanations? 


\section{Armed Peace}

In the months preceeding the signing of the Oregon Treaty the British fortified Vancouver Island and sent the British Pacific Squadron to patrol the Oregon coast, while the United States government sent army units to Oregon ostensibly to protect arriving American settlers. More importantly, the Americans alerted their fortifications on the Atlantic coast to the possibility that the British would press their claim to the Oregon territory by blockading and bombarding American coastal cities as the British had done in the War of 1812. At the same time the British increased their fortifications around the Great Lakes for fear that the Americans would press their claim to the Oregon territory by again invading Ontario and the St. Lawrence Valley.

Thus, while the United States and Great Britain were negotiating a peaceful settlement of their dispute over the Oregon territory, they also were arming and preparing for the possibility of war. In this respect the Oregon Treaty was a typical peaceful settlement of a territorial dispute between sovereign states in that it was initially an armed peace. Although the settling of territorial disputes peacefully is common, and even routine, peaceful settlements of territorial disputes rarely call for the resulting border to be unfortified. ${ }^{5}$

The idea that fortifications can make a peaceful settlement of a territorial dispute possible is embodied in the popular observation, "Good fences make good neighbors." More generally the possibility of arming for peace is embodied in an ancient prescription: Qui desiderat pacem, preparet bellum. ${ }^{6}$

But, even if war is avoided, fortifying a border is costly. Accordingly, just as it is

\footnotetext{
${ }^{5}$ In this context we define fortifications to include not only defensive positions such as those on Vancouver Island, or like the Maginot Line and the Seigfried Line, that were literally on the border, but also to include all costly preparations for the possibility of war over a contested territory, such as the repositioning of British warships off the Atlantic coast of the United States in anticipation of a war over the Oregon territory.

${ }^{6}$ The theory of armed peace derives from the seminal work of Garfinkel (1990) and Robert Powell (1993) on the strategic role of arms.
} 
natural to conjecture that, because war is costly and risky, every territorial dispute affords a peaceful settlement, it is also natural to conjecture that every territorial dispute also affords a settlement that includes an agreement not to fortify the resulting border. Moreover, as we know, the United States and Canada eventually supplemented the Oregon Treaty with an implicit understanding not to fortify the border between United States and Canada.

These observations present us with another pair of questions to answer:

Although sovereign states settle most of their territorial disputes peacefully, why don't most peaceful settlements include agreements not to fortify the resulting border, and why have the United States and Canada been an exception?

\section{Credibility}

The key to answering each of the questions that I have raised is to recognize that a peaceful settlement has to be credible. ${ }^{7}$ We can state this requirement more precisely as follows:

States can successfully negotiate a peaceful settlement that divides a contested territory between them only if each state can credibly promise not to start a war in an attempt to gain control of more territory.

What criterion do negotiators use to assess the credibility of a promise not to start a war?

A state would think that another state's promise not to start a war is credible only if the other state would be better off by keeping its promise not to start a war than by breaking its promise.

\footnotetext{
${ }^{7}$ The discussion that follows draws heavily on the comprehensive analysis of the causes of war by James Fearon (1995). Fearon begins by asking about the existence of a "bargaining range", which would comprise "a set of negotiated settlements that both sides prefer to fighting". Later on he asks about the credibility of such negotiated settlements. In contrast, because the set of credible peaceful settlements is a subset of the bargaining range, I prefer to cut to the chase by analyzing credibility at the start.
} 
Unfortunately, this criterion presents the following dilemma:

Each state would be better off keeping its promise not to start a war if a peaceful settlement would give it a large share of the contested territory. But, a peaceful settlement can give one state a large share of the contested territory only by giving the other state a small share.

The essential question for negotiators is whether they can divide the contested territory in such a way that each state gets a large enough share to induce it to keep its promise not to start a war.

Negotiators also would recognize that a state would be more tempted to break its promise not to start a war

- if it puts a high value on control of the entire contested territory and

- if it attaches a high probability to its winning a war that it starts.

In addition negotiators would recognize that the probability that a state attaches to its winning a war that it starts would depend on the strength of the defenses and possible counterattacks with which as an attacker it would expect to have to contend.

This analysis would enable realistic negotiators to address the following questions about hypothetical peaceful settlements that divide the contested territory:

- Is it possible to divide a contested territory in such a way that with an unfortified border promises not to start a war would be credible?

- If not, would a fortified border make such promises credible?

The preceding discussion suggests that the answers to these questions depend on two critical factors:

- the divisibility of the contested territory: Is the whole of a contested territory more valuable than the sum of its parts? 
- the advantage to attacking: Would a state that starts a war have to contend with a substantial counterattack?

Let us now look more carefully at these critical factors.

\section{Divisibility}

In a peaceful settlement of a territorial dispute the states typically divide the contested territory. But, in some cases the whole of a contested territory is more valuable than the sum of its parts, making division of the territory costly. If the winner of a war would gain control of the entire territory, and if the whole of a contested territory is sufficiently more valuable than the sum of its parts, then, despite the costs and risks of war, promises not to start a war could be not credible, and a peaceful settlement, or at least a peaceful settlement with unfortified borders, would not be possible.

As an example of a contested territory being costly to divide, the value of natural resources in the interior of the territory, like furs in the Oregon territory, can depend on their being easily transported to a seaport on the territory's coast for shipment abroad. In this example, which accords with the strong aversion that sovereign states have to being landlocked, control of the interior of the territory alone has little value. Fortunately, in the Oregon Treaty of 1846 the United States and Great Britain were able to minimize the costs of dividing the territory and to solve a perceived problem of access to the sea by giving the British rights of navigation on the Columbia River.

This example also bears on the American Civil War, the bloodiest war ever fought in North America. According to some historians one of the causes of the War was that the Union could not accept the existence of an independent Southern Confederacy that would have controlled access to the sea via the Mississippi River.

\section{Existential Disputes}

The dispute over the Oregon territory did not concern the survival of the either United States or Great Britain as sovereign states or even, as it might have, the issue of whether the 
United States would tolerate a British presence in North America. In this sense the dispute was not existential. Had the dispute been existential it probably would not have afforded the possibility of a peaceful settlement.

To see the difference between nonexistential and existential disputes contrast the First and Second Punic Wars with the Third Punic War. In the First Punic War (264-241 BCE) and also in the Second Punic War (218-201 BCE) Rome and Carthage fought over control of some Mediterranean islands and Iberia. Neither Rome nor Carthage was attempting to conquer and to destroy the other. Hence, their territorial disputes apparently afforded the possibility of peaceful settlements involving division of the contested territories. It seems that Rome and Carthage did not reach peaceful settlements only because the Carthaginians were overly optimistic about their prospects of winning these wars.

In contrast, in the Third Punic War (149-146 BCE) the Roman objective was to gain a commercial monopoly in the Mediterranean Sea. To achieve this objective the Romans recognized that, as Cato the Censor chanted, "Carthage must be destroyed" or, at least, subjugated. In this dispute the issue was existential, and the outcome was indivisible. Either Rome would or would not conquer Carthage.

Perhaps the most common examples of existential disputes with indivisible outcomes are disputes about secession, such as the disputes that resulted in the American War of Independence and the American Civil War, more accurately called the War for Southern Independence. The ongoing dispute between Arabs and Israelis provides a similar example. Over the years the Arabs have rejected every proposal for a peaceful settlement that would divide Palestine into a Jewish state and an Arab state, because for the Arabs allowing a Jewish state would be a defeat, not a compromise. The Israelis, however, demand a Jewish state, and they refuse to turn all of Palestine into a single multinational state in which Jews would not make up a large majority of the population.

If the dispute between Arabs and Israelis were about the control of tracts of land or 
sources of water, then a peaceful settlement might have been possible long ago. But, the dispute is about the existence of a Jewish state, and the outcome is indivisible. Is there or is there not to be a Jewish state in Palestine? The answer is either yes or no.

\section{Side Payments}

In some cases either side payments or linkages among issues can get around the problems of costly division or indivisibility. The idea of a side payment is that one state concedes to the demands of the other state with regard to the dispute at hand, thereby avoiding a costly division of the contested territory, in exchange for monetary or other compensation. This possibility requires that at least one of the states has the resources to provide adequate compensation to the other state.

The related idea of a linkage among issues is that one state concedes to the demands of the other state in one set of disputes, in exchange for which the other state concedes in another set of disputes between these states. This possibility requires that the two states have simultaneous disputes that they can combine into sets of comparable importance.

It seems clear that in many historical cases side payments or linkages among issues were not feasible. For example, once the Romans had set their sights on a commercial monopoly in the Mediterranean Sea, there was no possibility that the Carthaginians could pay the Romans enough to dissuade the Romans from trying to subjugate or to destroy Carthage. Similarly, there seems to be no possibility that the Arabs could pay the Israelis enough to persuade the Israelis to give up their goal of a Jewish state in Palestine. ${ }^{8}$

\section{Counterattacks}

An unfortified or lightly fortified border creates a temptation for an opponent to attack

- that is, to start a war by striking first. But, if, in response to an attack, a state would

${ }^{8}$ Fearon (1995) argues on the basis of some examples that either side payments or linkages "typically" are feasible. Hence, he concludes that indivisibility does not provide a "compelling" reason for failure to settle a dispute peacefully. 
be able to mobilize resources to mount an effective counterattack, then an attacker would expect to have to contend with more than a defender's fortifications, and the temptation to attack would be mitigated.

The ability of a state to mount an effective counterattack depends on variety of factors, including geography, technology, and military organization. The important point is that the prospect of an effective counterattack would deter a state from breaking a promise not to start a war and could make such a promise credible. For example, although the primary mission of the British Atlantic fleet did not involve the dispute over the Oregon territory, the possibility that the Admiralty could move the fleet into position to threaten the Atlantic coast of the United States surely helped to make the Oregon Treaty possible. The strength of the Atlantic fleet also enabled the British to spend less on directly fortifying the border between the United States and Canada.

\section{Overoptimism}

I have speculated that Rome and Carthage did not reach peaceful settlements that would have avoided the First and Second Punic Wars because the Carthaginians were overly optimistic about their prospects of winning these wars. Overoptimism is most likely to result from underestimation of attributes that would enable an opponent to wage war successfully, such as the effectives of an opponent's military forces, the willingness of an opponent to incur the costs of war and to bear the risks of war, and the ability of an opponent to mobilize resources to mount an effective counterattack. Whatever its cause overoptimism can preclude a peaceful settlement, or it can mean that a peaceful settlement requires more fortifications. ${ }^{9}$

It is easy to underestimate an opponent because many of an opponent's attributes are

\footnotetext{
${ }^{9}$ Dagobert Brito and Michael Intriligator (1985) provide a seminal analysis of how overoptimism can prevent a peaceful settlement of a dispute. In their example overoptimism results from underestimation of the importance of a dispute to an opponent. Fearon (1995) also emphasizes the importance of overoptimism as a cause of war. A similar analysis would apply if the states underestimate the costs of war.
} 
likely to be the opponent's private information, or at least to be best known to the opponent itself. $^{10}$ In addition, to enhance its bargaining strength in negotiations for a peaceful settlement each state has an incentive to make exaggerated claims about its ability to wage war successfully. But, recognizing this incentive to dissemble each state will discount any claims made by its opponent, unless it can independently verify that these claims are true.

If a state is unable to verify the claims made by an opponent, then its estimation of this opponent has to be based on imperfect intelligence, the main source of which is likely to be the performance of this opponent in previous wars. But, suppose that this opponent has achieved recent improvements in its ability to wage war successfully, with these improvements reflecting underlying innovations in weaponry or in military tactics. If this opponent has not yet demonstrated the effectiveness of these innovations, and especially if a desire to maximize the effectiveness of these innovations deters the opponent from revealing too much about them, then intelligence is likely to provide an outdated assessment that would result in overestimation of the probability of winning a war against this opponent.

Historically, overoptimism about the prospects of winning a war seems often to have been a factor both in preventing peaceful settlements of new disputes and also in causing existing peaceful settlements of old disputes to break down. Prior to the Mexican-American War the Mexicans rejected American proposals to adjust the border peacefully apparently because, having observed the recent poor performance of the American army in the Second Seminole War, and not being aware that the Americans had since shaped up their army, the Mexicans underestimated the ability of the American army. Other apparent examples of overoptimism from the modern history of warfare include the Russians in the Russo-Japanese War (1904), the Central Powers in the First World War (1914), the Axis Powers in the Second World War (1939), the North Koreans in the Korean War (1951), the Americans in the Vietnam

\footnotetext{
${ }^{10}$ It is also possible, but less likely, for the leaders of a state to be overly optimistic because they overestimate either the effectiveness of their own military forces or their own willingness to incur the costs and to bear the risks of war.
} 
War (1964), the Argentines in the Falkland/Malvinas Islands War (1982), and the Iraqis in the Iraq War (2003). ${ }^{11}$ In contrast to these examples in 1846 the Americans and the British each apparently knew enough about the ability the other to wage war successfully to be able to settle the dispute over the Oregon territory peacefully.

Although overoptimism about the prospects of winning a war can cause a dispute to result in war, the experience of war can cure overoptimism and, thereby, can provide the basis for peaceful settlements of both old disputes and newly arising disputes. For example, the lessons learned from the Mexican-American War induced the Mexicans not only to agree to every immediate American territorial demand in the Treaty of Guadalupe Hidalgo of 1848, but also to agree to further American territorial demands in the Gadsden Purchase of 1853.

Sometimes a third party learns important lessons from war. For example, according to some historians, the dropping of atomic bombs on Japan, by demonstrating that United States had this weapon and was willing to use it, helped to prevent the Soviet Union from being overly optimistic about winning a war with the United States, and thereby helped to prevent a war between the United States and the Soviet Union. Similarly, some historians attribute the American military interventions in Korea and in Vietnam in part to a desire to demonstrate that the United States was willing to incur the costs of war in order to contain "international communism". According to Iwan Morgan (1995, page 30), "[President] Johnson told Congress in 1965: 'The aim [of the communists] in Viet-Nam is not simply the conquest of the South...It is to show that the American commitment is worthless. Once that is done, the gates are down and the road is open to expansion and endless conquest."' As Fearon (1995, page 400) puts it, "States employ war itself as a costly signal of privately known and otherwise unverifiable information about willingness to fight...[and] as a credible

\footnotetext{
${ }^{11}$ Fearon (1995) explains how in the Russo-Japanese War outdated Russian intelligence underestimated the effectiveness of the Japanese military forces and how in the First World War the Central Powers underestimated the willingness of the Allies to incur the costs of war. The Axis Powers apparently repeated this mistake in the Second World War.
} 
means to reveal private information about their military capabilities."

Sometimes, however, overoptimism can be persistent. The endemic warfare between Arabs and Israelis provides a pathological example. Arab rhetoric equates the Zionist project of establishing a Jewish state in Palestine to the creation of a colony. As long as the Arabs believe their own argument that Zionism is an instance of colonialism, the lessons that the Arabs glean from past conflicts between colonial settlers and indigenous peoples are relevant to prospects for peace between Arabs and Israelis. The problem is that the Arabs seem to be overly optimistic in taking examples such as Algeria and South Africa, where colonialism ultimately failed, to be models for their conflict with Zionism. An end to warfare between Arabs and Israelis seems unlikely not only because, as already pointed out, the Arabs are unwilling to accept a Jewish state in Palestine, but also because the Arabs believe that they do not have to accept a Jewish state in Palestine.

\section{Surprise Attacks}

In September 1938 at Munich Great Britain and France reached an agreement with Germany that conceded Hitler's demand to annex the Sudetenland to Germany. When Chamberlain and Daladier negotiated this agreement, apparently they thought that Hitler's promise not to attempt to gain control of more territory was credible. As William Shirer (1960, page 387) tells us, “...the Prime Minister [Chamberlain] had great confidence in the Fuehrer's word, remarking privately ..., 'In spite of the hardness and ruthlessness I thought I saw in [Hitler's] face, I got the impression that here was a man who could be relied upon when he had given his word."

Less than a year later von Ribbentrop and Molotov negotiated the German-Soviet Nonaggression Pact. This Pact and its various secret protocols divided control of Poland and the Baltic states between Germany and the Soviet Union. When Stalin agreed to this Pact, which was signed in his presence, Stalin, like Chamberlain and Daladier before him, also apparently thought that a promise by Hitler not to attempt to gain control of more territory 
was credible. According to Gerhard Weinberg (1994, pages 162, 165-6), early in 1940 the British ambassador to Moscow reported that "Stalin professed to see no danger threatening the Soviet Union from Germany," and as late as the winter of 1941 Soviet planning discounted the possibility of a German invasion.

In both cases Hitler broke his promises. Within months Germany abrogated the Munich agreement by seizing control of the rest of Czechoslovakia. Presumably Chamberlain and Daladier were surprised. Hitler had confounded what Shirer refers to as Chamberlain's "comforting illusions" that the Munich agreements had achieved "peace in our time".

In June 1941 Germany abrogated the German-Soviet Nonaggression Pact by launching Operation Barbarossa, an invasion of the Soviet Union. By every indication Stalin certainly was surprised. In hindsight Chamberlain and Daladier in 1938 and Stalin in 1939 were wrong to think that they had achieved peaceful settlements of German territorial demands.

After Hitler surprised the British and the French and subsequently surprised Stalin, it was Hitler's turn to be surprised. By September 1939, when Germany invaded Poland, the British and French could no longer have thought that a peaceful settlement with German was possible. But, apparently Hitler was surprised that Great Britain and France were unwilling to acquiesce in further German aggression in the East and declared war on Germany. A.J.P. Taylor (1961, page 70) tells us, "Against all expectations, Hitler found himself at war with the Western Powers before he had conquered the East." 12

Later, in launching the Battle of Britain Hitler seems to have underestimated both the effectiveness of the Royal Air Force and the willingness of the British to incur the costs of an intense and protracted war. British innovations in weaponry, most importantly radar and

\footnotetext{
${ }^{12}$ Whether Hitler had ultimate territorial ambitions in western Europe is not clear. Taylor (1961, page 70) argues that "eastern expansion was the primary purpose of [Hitler's] policy, if not the only one." But, other historians suggest that the Nazis intended all along to incorporate western Europe into their empire. See, for example, Weinberg (1994, page 107). Grossman and Mendoza (2002) analyze the strategies that Nazi Germany used in central and eastern Europe to build its short-lived empire.
} 
the Spitfire interceptor, as well as the resilience of the British surprised the Germans. Shirer (1960, page 776) tells us that, according to the testimony of Adolf Galland, the famous German fighter ace, "We [Germans] realized that the R.A.F. fighter squadrons must be controlled from the ground by some new procedure because we heard commands skillfully and accurately directing Spitfires and Hurricanes on to German formations...For us this radar and fighter control was a surprise and a very bitter one." Shirer (1960, pages 760-761) also tells us that after Dunkirk General Jodl, the head of the German armed forces operations staff, expressed the belief that "since England can no longer fight for victory, but only for the preservation of its possessions and its world prestige she should, according to all predictions, be inclined to make peace when she learns that she can still get it now at relatively little cost." Shirer continues, "This was what Hitler thought too and he immediately set to work on his peace speech for the Reichstag."

Similarly, in launching Operation Barbarossa Hitler expected a quick and easy defeat of the Soviet Union, but he fatally underestimated the ability of the Soviet Union to mobilize massive amounts of manpower and resources in response to an attack. Horst Boog (1998, page 221) tells us that "... the decision to attack the Soviet Union failed to give rise to any appropriate efforts in the armaments sector. At no time was a maximum effort even considered - an effort commensurate with the enemy's potential - because the German leadership assumed that available forces were sufficient to smash the Soviet military potential within a few weeks." And, according to Weinberg (1994, page 273), "The Germans had no real concept of the rate at which the Soviet Union had been mobilizing new forces to introduce into the battle, and they were so far off in their view of Soviet power as to assert early in December [1941] that the Red Army had neither the ability nor the intention of launching any significant counter-offense of its own." The Soviet counterattack at Stalingrad was the ultimate surprise for Hitler.

The criterion that negotiators would use to assess the credibility of a promise not to 
start a war suggests that the critical failing of Chamberlain, Daladier, and Stalin was not to recognize the extent of Hitler's overoptimism about the prospects for German success in war. Had Chamberlain, Daladier, and Stalin known the extent to which Hitler underestimated the strength of the defenses and counterattacks, both British and Soviet, with which Germany would have to contend, it is unlikely that they would have assessed Hitler's promises not to start a war in an attempt to gain control of more territory to be credible.

I have previously suggested that German overoptimism about the prospects for German success in war was one of the causes of the Second World War. But, why did the prelude to this war include the negotiation of what Great Britain, France, and the Soviet Union thought incorrectly were peaceful settlements? The answer to this question seems to be that the British, French, and Soviet negotiators did not appreciate how overly optimistic Hitler was about how easy it would be for German military power to conquer Europe.

\section{Does War Settle a Dispute Permanently?}

A peaceful settlement with a fortified border typically involves both an initial cost of creating the required fortifications and continually recurring expenses, such as for salaries of soldiers and for maintenence of weapons and fortifications. If a state thinks, even if over optimistically, that a war would settle a territorial dispute permanently, then it would be tempted to start a war in order to avoid these recurring expenses. If deterring an attack would require large recurring expenses, then a war that would settle a dispute permanently could appear to be less costly than a peaceful settlement. ${ }^{13}$

A related possibility arises if one state thinks that the other state is improving its ability to wage war successfully and that, consequently, in the future the other state will be able to demand a large share of the contested territory. In this case a state would be tempted to start a war now in order to avoid having to deal with a stronger opponent in the future. Some historians suggest that a perception that Russian military power was increasing was a

\footnotetext{
${ }^{13}$ See Garfinkel and Stergios Skaperdas (2000) for further analysis of this possibility.
} 
factor in inducing Germany and Austria to go to war in $1914 .^{14}$

Alternatively, if a war would not settle a territorial dispute permanently, then whatever advantage a state that attacks an unfortified border would get in determining the outcome of the dispute would be only temporary. In addition, by breaking a promise not to start a war a state would make it difficult, if not impossible, to negotiate a new peaceful settlement in the future. The prospect of having to incur the costs and to bear the risks of war indefinitely into the future would mitigate the temptation to start a war and could make promises not to start a war credible. ${ }^{15}$

\section{Territorial Disputes: Summary}

For more than a century the borders between the United States and Canada have been both undisputed and unfortified. The United States and Canada not only have avoided war but we also have avoided the potentially large costs of fortifying their border. Why have not all sovereign states that have territorial disputes emulated us?

Our theory of the choice between peace and war implies that, despite the costs and risks of war, if a dispute is existential, or, more generally, if the whole of a contested territory is sufficiently more valuable than the sum of its parts, then a peaceful settlement is not possible. A peaceful settlement of a territorial dispute, and especially a settlement that includes an agreement not to fortify the resulting border, also can be impossible if a state thinks, even if over optimistically, that by starting a war it would be able at a small cost to settle the dispute completely in its favor permanently.

Conversely, our theory implies that the following circumstances help to make a peaceful settlement of a territorial dispute possible:

\footnotetext{
${ }^{14}$ Fearon (1995) discusses at some length this possibility, which he calls a "preventive war", as well as its relevance to the First World War.

${ }^{15}$ Grossman (2003a) argues that this analysis helps to explain the peaceful settlement of the dispute over the Oregon territory.
} 
- Either dividing the contested territory is not costly or side payments can make it possible to avoid a costly division of a contested territory.

- A state that started a war by striking first would have to contend with a substantial counterattack.

- A war would not settle the territorial dispute permanently, and the breaking of a promise not to start a war would make it difficult, if not impossible, to negotiate a new peaceful settlement in the future.

History suggests that all of these circumstances contributed to the peaceful settlement of the dispute over the Oregon territory as well as to the subsequent understanding that the border between the United States and Canada would be unfortified.

Our theory also allows for the possibility that in some cases a peaceful settlement can require the resulting border to be fortified, because it is too tempting for one state to start a war if the other state has not fortified the border. With a fortified border fortifications deter each state from breaking a promise not to start a war.

\section{Civil Wars}

So far we have focused on territorial disputes between sovereign states. But, disputes between groups that are part of the same polity are at least as ubiquitous as disputes between sovereign states, and civil wars are at least as common as wars between sovereign states. ${ }^{16}$

The constituent groups of a polity that are involved in disputes can be either narrow, like rival ruling elites or rival political cliques, or broad, like clans, ethnic groups, or social classes. The disputes that arise between these groups can involve a single issue or, more

\footnotetext{
${ }^{16}$ In some cases these classifications are ambiguous. For example, the parties to a dispute about secession are initially part of the same polity, but, if a dispute about secession results in a war of independence, then the parties to the war are self-proclaimed sovereign states.
} 
likely, a sequence of different, although possibly related, issues. Examples of issues that can cause recurring disputes between constituent groups of a polity include the following:

- A political squabble: the share of political patronage that goes to the politicians associated with one clique rather than another.

- A divisive distributional issue: the share of national income that goes to one social class rather than another.

- A divisive ideological issue: the degree of tolerance for the religious practices of one ethnic group, these practices being offensive to another ethnic group.

The possibilities for peaceful settlements of disputes between constituent groups of a polity differ from the possibilities for peaceful settlements of disputes between sovereign states in at least two important ways:

- First, an armed peace involving constituent groups of the same polity is not possible, unless the polity is dissolved by secession.

- Second, a peaceful settlement of recurring disputes between constituent groups of the same polity does not have to specify the outcome of each dispute, but instead can specify a constitution that prescribes a peaceful political process for determining the outcomes of disputes.

Actual constitutional political processes vary widely. In electoral democracies constitutional contests involve periodic competition for the votes of an electorate. In contrast, in aristocracies constitutional contests involve competition for the favor of wise men, elders, or hereditary rulers. Many constitutions combine democratic and aristocratic features. For example, under the Constitution of the United States in 1876 and again in 2000 inconclusive electoral competitions led to second competitions in which the candidates for President competed for the favor of a Supreme Court of appointed judges. 
In any case the political process prescribed by any constitution includes two essential components:

- first, the nature of constitutional contests between parties to disputes;

- second, the prerogatives of winners of these constitutional contests.

In addition, any constitution must overcome a formidable hurdle if it is to provide a viable alternative to civil war:

Because the constituent groups of a polity cannot make binding commitments to abide by a constitution, a constitutional political process provides a viable alternative to civil war only if the parties voluntarily choose to accept the outcome of this political process - that is, only if the constitution is self enforcing.

What are the factors that determine whether or not it possible to design a self-enforcing constitution that can settle recurring disputes between constituent groups of a polity? Both theoretical analysis and historical experience suggest the same answer to this question: ${ }^{17}$

A self-enforcing constitution is possible only if the constituent groups of a polity expect the incremental costs of civil conflict to be large relative to the importance of the disputes that arise between them.

Conversely, as long as the expected incremental costs of civil war are not too large, constitutional political processes cannot settle important disputes.

The American Civil War provides an interesting example. For the first seventy years of the republic artful compromises enabled Northern and Southern interests to find peaceful settlements of their disputes, which centered on slavery. But, historical analysis suggests that in the years leading up to 1861 the outcome of the dispute over slavery became too

\footnotetext{
${ }^{17}$ The relevant theoretical analysis is developed in Grossman (2003d, 2004).
} 
important to both Northern and Southern interests, relative to the expected costs and the risks of war, for secession and war to be avoided. In the end Northern interests would not agree not to impose restrictions on the property rights of slave owners that Southern interests viewed to be intolerable. ${ }^{18}$ In sum, if the constituent groups of a polity are deeply divided and, hence, are unwilling to accept meaningful limitations on the prerogatives of winners of constitutional contests, then civil war can be unavoidable.

${ }^{18}$ See Grossman (2003b) for an extended analysis of the causes of secession and war. 


\section{References}

Alesina, Alberto, and Spolaore, Enrico. "On the Number and Size of Nations", Quarterly Journal of Economics, 112(4), November 1997, 1027-1056.

Alesina, Alberto, and Spolaore, Enrico. The Size of Nations, MIT Press, 2003.

Alesina, Alberto, and Spolaore, Enrico. "War, Peace, and the Size of Countries", Journal of Public Economics, forthcoming, 2004.

Boog, Horst et al. The Attack on the Soviet Union, Translated by Dean S. McMurry, Ewald Osers, and Louise Willmot. Clarendon Press, 1998.

Brito, Dagobert and Intriligator, Michael. "Conflict, War, and Redistribution", American Political Science Review, 79, December 1985, 943-957.

Fearon, James D. "Rationalist Explanations for War", International Organization, 49(3), Summer 1995, 379-414.

Garfinkel, Michelle. "Arming as a Strategic Investment in a Cooperative Equilibrium", American Economic Review, 80(1), March 1990, 50-68.

Garfinkel, Michelle. "Domestic Politics and International Conflict", American Economic Review, 84(5), December 1994, 1294-1309.

Garfinkel, Michelle and Skaperdas, Stergios, "Conflict Without Misperceptions or Incomplete Information: How the Future Matters," Journal of Conflict Resolution, 44(6), December 2000, 793-807.

Gershenson, Dmitriy and Grossman, Herschel I. "Civil Conflict: Ended or Never Ending?" Journal of Conflict Resolution, 44(6), December 2000, 807-821.

Grossman, Herschel I. "Fifty-four Forty or Fight!" NBER working paper w9635, April 2003a.

Grossman, Herschel I. "...and six hundred thousand men were dead.” NBER working paper w9793, June 2003b.

Grossman, Herschel I. "Peace and War in Territorial Disputes", unpublished, November 
2003c.

Grossman, Herschel I. "Distributional Disputes and Civil Conflict", Cuadernos de Economía, 40(121), December 2003d.

Grossman, Herschel I. "Constitution or Conflict?" Conflict Management and Peace Science, forthcoming, 2004.

Grossman, Herschel I. and Kim, Minseong. "Swords or Plowshares? A Theory of the Security of Claims to Property", Journal of Political Economy, 103(6), December 1995, 1275-1288.

Grossman, Herschel I. and Mendoza, Juan. "Annexation or Conquest? The Economics of Empire Building", unpublished, September 2002.

Hess, Gregory and Orphanides, Athanasios. "War Politics: An Economic, Rational-Voter Framework", American Economic Review, 85(4), September 1995, 828-846.

Hess, Gregory and Orphanides, Athanasios. "War and Democracy", Journal of Political Economy, 109(4), August 2001, 776-810.

Miles, Edwin A. "Fifty-four Forty or Fight' - An American Political Legend", The Mississippi Valley Historical Review, 44(2), September 1957, 291-309.

Morgan, Iwan W. Beyond the Liberal Consensus: A Political History of the United States since 1965, St. Martin's Press, 1994.

Pletcher, David M. The Diplomacy of Annexation: Texas, Oregon, and the Mexican War, University of Missouri Press, 1973.

Powell, Robert. "Guns, Butter, and Anarchy", American Political Science Review, 87(1), March 1993, 115-132; adapted as Chapter 2 in Powell (1999).

Powell, Robert. In the Shadow of Power: States and Strategies in International Politics, Princeton University Press, 1999.

Shirer, William L. The Rise and Fall of the Third Reich: A History of Nazi Germany, Simon and Schuster, 1960. 
Sperber, Hans. "Fifty-four Forty or Fight': Facts and Fictions", American Speech, 32(1), February 1957, 5-11.

Taylor, A. J. P. The Origins of the Second World War, Atheneum, 1961.

Weinberg, Gerhard L. A World at Arms: A Global History of World War II, Cambridge University Press, 1994. 